\title{
The Role of Platelets in the Pathogenesis of Viral Hemorrhagic Fevers
}

\author{
Juan C. Zapata ${ }^{1 *}$, Dermot Cox ${ }^{2}$, Maria S. Salvato ${ }^{1}$
}

1 Institute of Human Virology, University of Maryland School of Medicine, Baltimore, Maryland, United States of America, 2 Molecular and Cellular Therapeutics School of Pharmacy, Royal College of Surgeons in Ireland, Dublin, Ireland

\begin{abstract}
Viral hemorrhagic fevers (VHF) are acute zoonotic diseases that, early on, seem to cause platelet destruction or dysfunction. Here we present the four major ways viruses affect platelet development and function and new evidence of molecular factors that are preferentially induced by the more pathogenic members of the families Flaviviridae, Bunyaviridae, Arenaviridae, and Filoviridae. A systematic search was performed through the main medical electronic databases using as parameters all current findings concerning platelets in VHF. Additionally, the review contains information from conference proceedings.
\end{abstract}

\section{Introduction}

Viral hemorrhagic fevers (VHFs) are a group of zoonotic diseases characterized by fever and bleeding disorders that can progress to shock and death. They are caused by different groups of viruses from the families Flaviviridae, Bunyaviridae, Arenaviridae, and Filoviridae [1,2]. In addition to the VHF syndrome, these viruses have other common characteristics: they are enveloped viruses with ssRNA genomes and cytoplasmic replication; some of them share common viral sequences; and they use rodents, bats, or insects as natural reservoirs or vectors. Their circulation is geographically restricted by the habitats of their natural hosts, and human beings are incidental hosts. Outbreaks of VHF occur sporadically; consequently, these viruses are continuously emerging or re-emerging in places where they find the ideal conditions. Most of these viruses are pantropic, and dendritic cells (DC), monocytes and/or macrophages are among the targets. Some subsets of those cells are highly susceptible to VHF, producing a large amount of virus early after infection that modifies the cell's antigen-presenting and cytokine-producing functions [3-8]. This could contribute to the pathogenesis observed in most of the VHFs, in which severe cases are associated with uncontrolled viral replication and high levels of viremia. Unfortunately, more disease treatment possibilities and immune prevention options are needed (Table 1) [2].

\section{Impact and Epidemiology of VHF}

The exploitation of new ecological niches by human beings and increased travel and trade have promoted the emergence or reemergence of VHF around the world (Figure 1). All VHFs are considered zoonotic diseases and their transmission mechanism varies from virus to virus. For instance, infection may be through insect bites or through contact with meat or excreta from infected animals.

Prioritizing the impact of each of these VHF diseases is important in order to develop effective control and prevention methods and reduce the annual loss of life. Together VHF diseases affect more than 100 million people around the world and kill more than 60,000 annually. The epidemiology and transmission of each disease differs greatly (Table 2).

Dengue virus (DENV) from the Flaviviridae is the most prevalent arthropod-borne VHF. Dengue is present on all continents, with new cases occurring and spreading to non-endemic areas in the United States and Europe (Figure 1; Table 2) [9-12]. Between 50100 million cases of dengue fever and around 500,000 cases of dengue hemorrhagic fever (DHF) or shock syndrome (DSS) are reported every year, with estimated case fatality rates ranging between $1 \%$ and 5\% [13]. Yellow fever (YF) virus, another flavivirus, is the second most globally distributed arthropod-borne disease, causing around 200,000 cases per year, with case fatality varying between $15 \%$ and $30 \%$. Although there is an effective vaccine against YF disease, the number of infected people has increased in recent years, especially in urban Africa [14,15]. Kyasanur Forest disease virus (KFDV), also a flavivirus, circulates in mammals and birds from India, Saudi Arabia, and Republic of China. KFDV is transmitted by forest ticks to humans and nonhuman primates, causing a severe febrile illness, sometimes with hemorrhagic symptoms [16]. Alkhumra virus, another flavivirus and a member of the mammalian tick-borne encephalitis group, is associated with acute VHF in Saudi Arabia, with fatality rates between $2 \%$ and $10 \%[17,18]$.

Lassa fever virus (LASV) and Lujo virus (LUJV), from the Old World subset of the Arenaviridae, are both from Africa. LASV is transmitted by rodents and causes around 300,000 cases of Lassa fever (LF) each year in West Africa, with an overall fatality rate around $1 \%$ that can range between $15 \%$ and $30 \%$ during hospital outbreaks $[19,20]$. LUJV was isolated in South Africa during a human outbreak characterized by nosocomial transmission and high fatality rates [21]. Since this outbreak, no new cases have been reported and its reservoir is still unknown. Junin (JUNV), Machupo (MACV), and Guanarito (GTOV) belong to the New World subset of the Arenaviridae and, together, are known as South

Citation: Zapata JC, Cox D, Salvato MS (2014) The Role of Platelets in the Pathogenesis of Viral Hemorrhagic Fevers. PLoS Negl Trop Dis 8(6): e2858. doi:10. 1371/journal.pntd.0002858

Editor: Ann M. Powers, Centers for Disease Control and Prevention, United States of America

Published June 12, 2014

Copyright: (c) 2014 Zapata et al. This is an open-access article distributed under the terms of the Creative Commons Attribution License, which permits unrestricted use, distribution, and reproduction in any medium, provided the original author and source are credited.

Funding: We would like to acknowledge support from Dr. Robert C Gallo, Director of the Institute of Human Virology, University of Maryland Medical School and NIH grants 5RC2CA149001 and AI068961 to MSS. The funders had no role in study design, data collection and analysis, decision to publish, or preparation of the manuscript.

Competing Interests: The authors have declared that no competing interests exist.

*E-mail: jczapata@ihv.umaryland.edu 
Table 1. Common characteristics of hemorrhagic fever viruses.

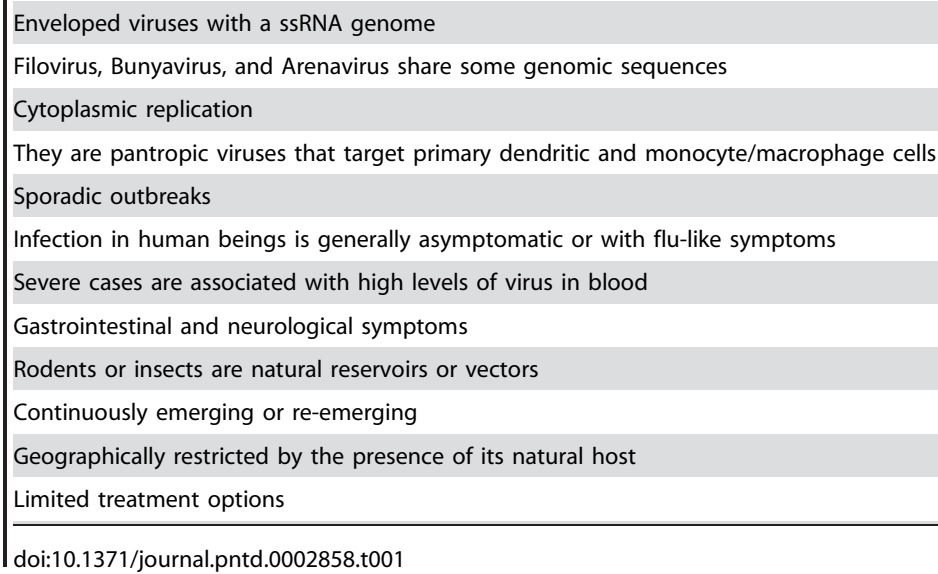

American hemorrhagic fever $(\mathrm{HF})$ viruses. These viruses circulate in rodents and occasionally are transmitted to human beings through the urine or feces of their carriers. JUNV causes Argentinian $\mathrm{HF}$ (AHF), with case fatality between 15\% and
$30 \%$. Since the introduction of the attenuated Candid \#1 vaccine the number of AHF cases has decreased dramatically $[22,23]$. MACV is responsible for Bolivian HF (BHF), with 13 cases of the disease reported in 2012 and seven deaths [24]. GTOV causes

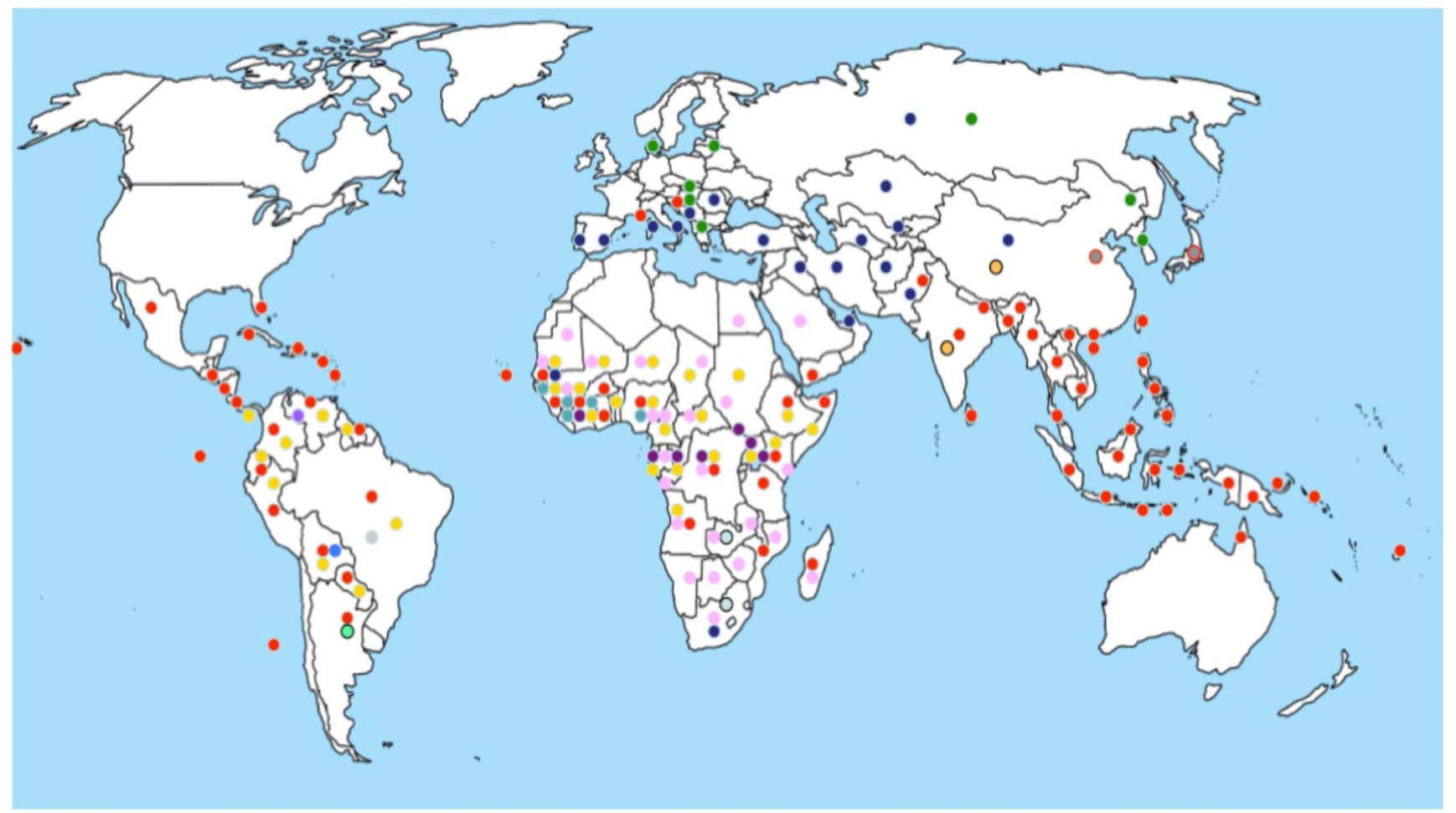

Flaviviridae

- Dengue virus

- Yellow fever virus

- Kyasanur forest disease
Bunyaviridae

- CCHF virus

- Hantavirus HFRS

Rift valley fever virus

SFTS virus
Arenaviridae

$\begin{array}{lll}\text { - Lassa virus } & \text { Machupo virus } \\ \text { - Lujo virus } & \text { - Guaranito virus } \\ \text { - Junin virus } & \text { - Sabiá virus }\end{array}$

\section{Filoviridae}

- Ebola and Marburg

Figure 1. Geographical distribution of Viral Hemorrhagic Fevers (VHF). This map shows the global distribution of some members of the viral families related to hemorrhagic fever disease. CCHF stands for Crimean Congo Hemorrhagic Fever and SFTS for severe fever with thrombocytopenia syndrome.

doi:10.1371/journal.pntd.0002858.g001 
Table 2. Impact of hemorrhagic fever viruses.

\begin{tabular}{|c|c|c|c|c|}
\hline Virus & Disease name & Cases/year & Estimated \% fatality rate & Death/year \\
\hline \multirow[t]{3}{*}{ Dengue } & Dengue Fever & 50-100 million [131] & & \\
\hline & Dengue HF (DHF) & 500,000 DHF [13] & $1 \%-5 \%$ & 22,000 DHF/DSS \\
\hline & Dengue shock syndrome (DSS) & & & \\
\hline Yellow Fever & Yellow Fever & $200,000[15]$ & $15 \%-30 \%$ & 30,000 \\
\hline $\begin{array}{l}\text { Kyasanur forest disease } \\
\text { virus }\end{array}$ & Kyasanur forest disease & $100-500[132]$ & $2 \%-10 \%$ & 1 \\
\hline Alkhumra virus & $\mathrm{HF}$ & $11[17,18]$ & $2 \%-10 \%$ & 3 \\
\hline $\mathrm{CCHF}$ & Crimean-Congo HF & $68[31,133]$ & $30 \%-60 \%$ & 3 \\
\hline Hantaan virus & $\begin{array}{l}\text { Hemorrhagic fever with renal syndrome } \\
\text { (HFRS) }\end{array}$ & $200,000[27]$ & $1 \%-15 \%$ & 10,000 \\
\hline Rift valley fever & & 34 [134] & $1 \%$ & 17 \\
\hline SFTS & $\begin{array}{l}\text { Severe fever with thrombocytopenia } \\
\text { syndrome (SFTS) }\end{array}$ & $171[34]$ & $12 \%-30 \%$ & 21 \\
\hline Lassa & Lassa fever & $300,000[19]$ & $1 \%-15 \%$ & 5,000 \\
\hline Lujo & HF & 5 & $80 \%$ & 4 \\
\hline Junin & Argentinian $\mathrm{HF}$ & $300-800[23]$ & $15 \%-30 \%$ & 300 (before vaccine) \\
\hline Machupo & Bolivian HF & 13 [24] & $18 \%-20 \%$ & 7 \\
\hline Guanarito & Venezuelan HF & $85[26]$ & $23.1 \%$ & \\
\hline Ebola & Ebola HF & $56[135]$ & $50 \%-90 \%$ & 37 \\
\hline Marburg & Marburg HF & 18 [39] & $25 \%$ & 9 \\
\hline Total & Hemorrhagic fever $=\mathrm{HF}$ & 〜51-101 million & & $\sim 67,000$ \\
\hline
\end{tabular}

Venezuelan HF in the western part of the country, with an estimated case-fatality rate of 23\% [25]. Between 2011 and 2012, more than 85 people acquired this disease [26].

Hantaan virus, Seol virus (SEOV), Crimean-Congo Hemorrhagic Fever (CCHF) virus, Rift Valley Fever virus, and Severe fever with Thrombocytopenia Syndrome (SFTS) virus belong to the family Bunyaviridae. These viruses gained importance in the last decade because they have been reported in places in which they are not endemic, with a tendency to continue expanding their circulation to other regions. Hantaan virus and SEOV, harbored and transmitted by contact with infected rodent excreta, cause close to 200,000 Hemorrhagic Fever with Renal Syndrome (HFRS) cases each year, with case fatality rates from $1 \%$ to $16 \%$ in Asia and the Far East Region of the Russia Federation [27]. Nephropathia epidemica, a mild form of HFRS caused by Puumala virus, is the most prevalent hantaviral disease in Western and Central Europe. All these viruses are widely distributed and continue to expand to new regions $[28,29]$. CGHF is a sporadic but often-fatal, tick-borne disease that is expanding through Europe, Asia, and Africa [30,31]. Rift Valley Fever virus is transmitted by mosquitos and also causes sporadic outbreaks of hemorrhagic fever in some African countries and, more recently, the Arabian peninsula, with variable mortality rates [32,33]. SFTS virus has recently emerged in China and Japan with mortality rates between $12 \%$ and $30 \%$ [34,35]. SFTS life cycle is still unknown; however, seroconversion and virus isolation involve domesticated animals as reservoirs and ticks as vectors [36]. It has been suggested that SFTS can also be transmitted through blood or personal contact with an infected patient [37].

Ebola and Marburg viruses (from the family Filoviridae) cause sporadic outbreaks amongst human and nonhuman primates in Central Africa (and recently, West Africa), with very high case fatality rates, ranging from $25 \%$ to $90 \%[38,39]$. These viruses are most often transmitted by direct contact with infected animals or people. The natural reservoirs for filoviruses are thought to be bats $[38,40]$.

Only two vaccines are licensed to prevent VHF: YF17D and Candid\#1, live-attenuated versions of the YF virus and JUNV. Unfortunately, the VHF-endemic areas are expanding, with the aggravation that treatments are limited or nonexistent. For this reason, it is important to continue research and development for new prevention and control options.

\section{Clinical Signs and Laboratory Findings}

VHF signs and symptoms range from asymptomatic infection to life-threatening disease. Initially, patients develop a nonspecific febrile syndrome (flu-like) that can include chills, malaise, headache, backache, arthralgia, myalgia, retro-orbital pain, anorexia, nausea, vomiting, diarrhea, cough, and sore throat [41-46]. At this stage the clinical signs resemble other infectious diseases, making early VHF clinical diagnoses impossible. Some cases progress to severe disease characterized by systemic vascular damage that, depending on the virus, will manifest as subcutaneous bleeding (flushing, conjunctivitis, peri-orbital edema, petechiae, or ecchymosis), positive tourniquet test, hypotension and internal organ bleeding, hematemesis, and melena [41-46]. The cause of bleeding in most VHF diseases is a disseminated intravascular coagulation (DIC) that depletes the coagulation factors, inducing massive plasma leakage, hypovolemia, and shock. A prolonged shock state leads to multiple organ failures and, in some cases, death. However, the loss of blood is rarely the cause of death (with the exception of filoviruses) [41-46]. 
The hallmark characteristic of all VHF is a decrease in platelet numbers and/or function. This decrease is usually accompanied by an increase in fibrinogen degradation products, prothrombin time (PT), and partial thromboplastin time (PTT). At least five days after the onset of fever, there is also a marked leucopenia and high viral loads that are associated with fatal outcomes. Another common finding is an increase in the alanine aminotransferase (ALT) and aspartate aminotransferase (AST) enzymes, primarily due to liver damage [41-46].

\section{VHF Pathogenesis}

Based on some clinical and laboratory findings (Table 3), different pathogenic mechanisms have been proposed for each VHF, including depletion of hepatic coagulation factors, cytokine storm, increased permeability by vascular endothelial growth factor, complement activation, and DIC. In spite of the differences seen with each VHF, there is a large body of evidence indicating that viral replication and host immune responses play an important role in determining disease severity and clinical outcome [47-50]. HF viruses can establish nonlytic replication, or "virus factories," in monocytes and/or macrophage and DC $[47,49]$. Viral replication subverts the function of these cells, as well as the function of uninfected bystander cells, to undermine the innate immune response, such as interferon (IFN) production. This leads to uncontrolled viral replication and to a lack of specific antiviral responses in the host [47-50]. These cells might also act as vehicles to carry the virus to its replication sites, such as endothelium, liver, spleen, and other organs, leading to the pantropism of most hemorrhagic fever viruses [47-50]. Whereas the early replication stage is characterized by a lack of IFN production and IFN-responsive gene expression, later viremic stages reveal an unregulated release of pro-inflammatory cytokines, such as tumor necrosis factor alpha (TNF- $\alpha$ ), IL-10, IL-1R $\alpha$, and soluble TNF-R, that could contribute to immunosuppression and increased vascular permeability, leading to hemorrhagic signs [51,52].

Thrombocytopenia (reduction of platelet numbers) and depressed immune responses are hallmarks of VHF, and platelets are involved in both processes; therefore, this review will focus on the platelet's role in VHF pathogenesis.

\section{Platelet Structure and Functions}

Platelets, also known as thrombocytes, are small, $2-3 \mu \mathrm{m}$, enucleated cell fragments derived from the cytoplasm of large, $100 \mu \mathrm{m}$, megakaryocytes (MKs) located in the bone marrow (Figure 2) [53]. Each MK sheds thousands of platelets into the blood stream, making them the second-most-abundant cell type in peripheral blood. Platelets' most-known function is to maintain the integrity of the vascular system [53]; however, their function as immune elements is becoming more evident.

Under specific stimulus, such as tissue damage, platelets are activated by extracellular matrix proteins, such as collagen and von Willebrand factor. Their irregular shapes swell to a compact spherical form with projections containing glycoprotein receptors that help them to attach to each other and to cells at wound sites [54]. After activation, platelets release granule contents and coagulation factors that further enhance their activation and cell attachment (Figure 3). This process results in the formation of an effective plug at the site of injury that supports formation of a fibrin network and stops bleeding [55].

There are some pathological processes in which the normal number of circulating platelets can decrease (thrombocytopenia), increase (thrombocytosis), or diminish in function (thrombasthenia) with or without hemostatic manifestations. The study of those conditions showed that in addition to their role in homeostasis, platelets are important mediators of inflammation and innate immunity [56]. Sub-products generated from microorganisms, from complement fixation reactions, or from expression of receptors such as $\mathrm{Fc}$ and $\mathrm{C} 3{ }_{\mathrm{a}} / \mathrm{C} 5_{\mathrm{a}}$ can attract platelets to the site of infection or injury where they are activated by thrombin and bind to vascular endothelial cells and leukocytes. Platelets can also bind pathogens directly, recognizing them through Toll-like receptors (TLRs), and can alert other cells via the innate immune response [57]. Platelets can directly release antimicrobial factors such as platelet factor 4 (PF-4), RANTES, connective tissue activating peptide 3 (CTAP-3), platelet basic protein, thymosin $\beta-4$ (T $\beta$-4), fibrinopeptide B (FP-B), fibrinopeptide A (FP-A), superoxide, hydrogen peroxide, and hydroxyl free radicals. Additionally, platelets participate in antibody-dependent cell cytotoxicity against microbial pathogens [58].

In conclusion, any pathogenic state affecting platelets will not only impact hemostasis but also will modify the immune response to infection. Although there are some advances in understanding the specific platelet activation mechanisms induced by some microorganisms, little is known about these interactions and their role in the pathogenesis of VHF.

\section{Direct and Indirect Virus-Platelet Interactions}

Several microorganisms or molecules derived from them interact with platelets and affect their function $[55,59,60]$. Virus-platelet interactions were initially described around 50 years ago with some in vitro experiments using influenza virus and other myxoviruses $[61,62]$. Since then, other viruses have been reported to interact not only with platelets but also with MKs [6368]. From these interactions, platelet numbers or functions can be compromised, and little is known about the exact mechanisms. In the case of VHF, recent publications described pathogenic mechanisms involving the role of platelets in homeostasis as well as their role in the initial immune responses in animals and human beings. The next paragraphs will describe different ways in which hemorrhagic fever viruses affect platelets.

There are four major causes of thrombocytopenia or platelet malfunction induced by viruses. These include direct effects of viruses on platelets, immunological platelet destruction, impaired megakaryopoiesis, and MK destruction (Table 4) [68]. In the VHF diseases, the most common mechanism of thrombocytopenia is platelet disappearance from damaged tissues or generalized virusinduced DIC, in which coagulation factors are depleted. This common pattern does not seem to apply to LASV. Additionally, there is some evidence that viruses not belonging to the hemorrhagic fever group (such as varicella, herpes zoster, smallpox, rubella, measles, cytomegalovirus, rotavirus, adenovirus, and HIV), under specific circumstances, can also cause hemostatic problems and can be associated with DIC [66,69-72]. More work is necessary to clarify the role of the platelet-virus interaction in coagulopathies and in DIC induced by both hemorrhagic and nonhemorrhagic viruses.

\section{Platelet-Virus Binding}

Platelets bind viruses through different receptors, such as $\beta-3$ integrins or TLRs, and platelets are known to express TLR2, TLR4, and TLR9 [73,74]. In severe sepsis, there are coagulation abnormalities and DIC that are thought to be due to TLR signaling in platelets [57]. Bacterial stimulation of platelet TLR2 increased P-selectin surface expression, activation of integrin $\alpha_{\mathrm{IIb}} \beta_{3}$, generation of reactive oxygen species, and formation of platelet-neutrophil heterotypic aggregates in human whole blood 


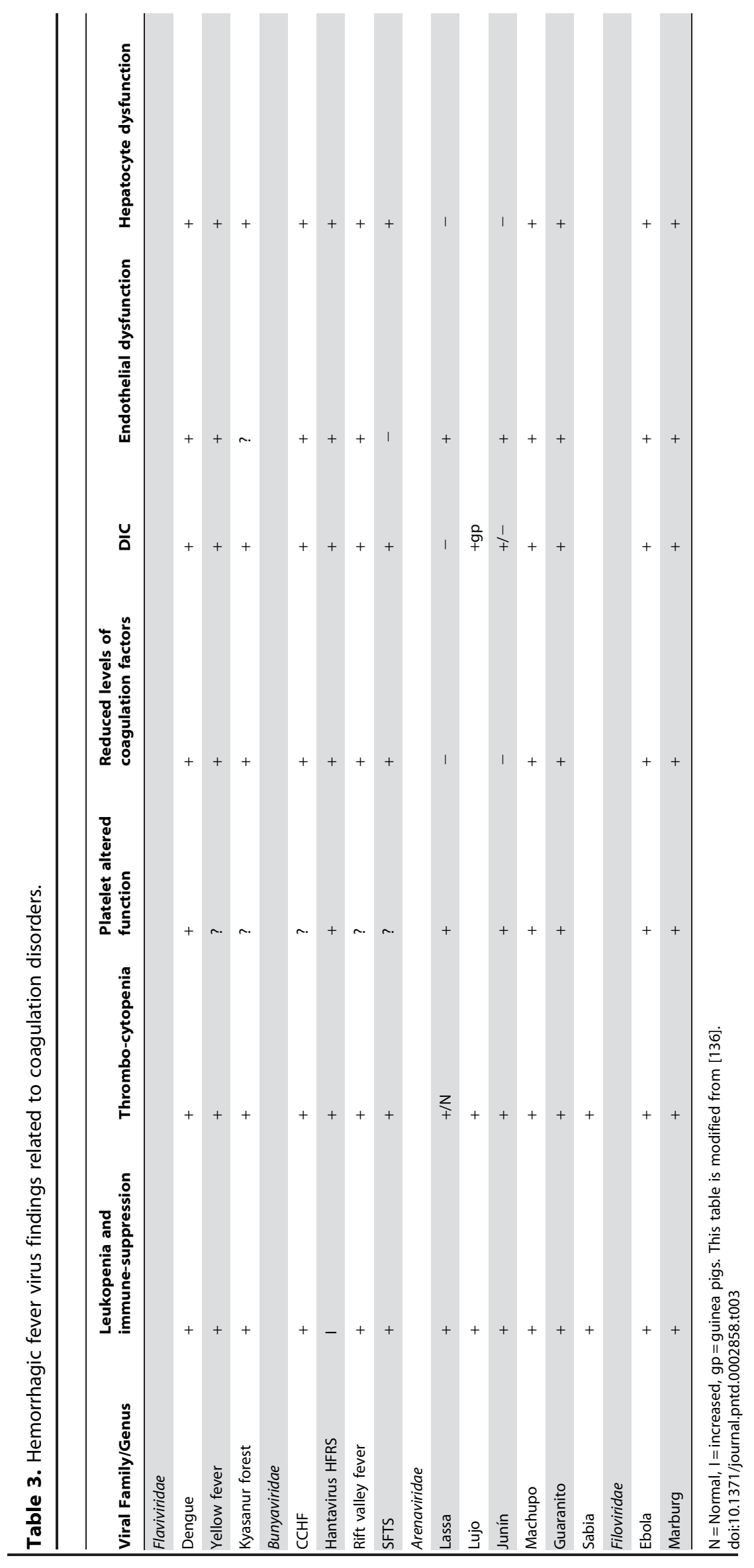




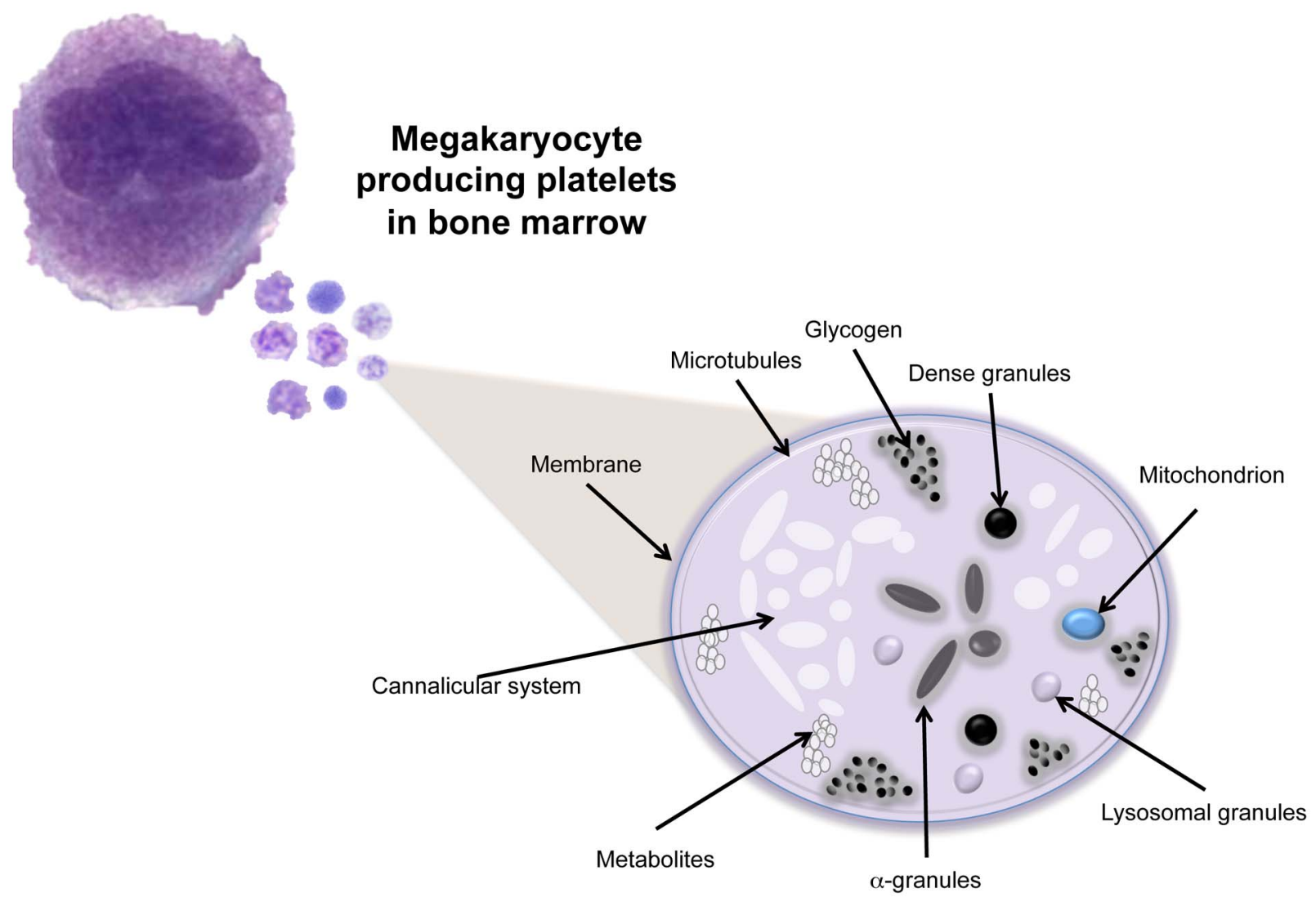

Platelet Structure

Figure 2. Platelet structure. Platelets have multiple surface receptors, a cannalicular system, microtubules, mitochondria, three types of granules (lysosomal, alpha, and dense), and deposits of small factors like glycogen (Figure 2 and 3) [54]. Whereas dense granules contain factors that potentiate platelet activation, $\alpha$-granules contain growth factors and clotting proteins that contribute to hemostasis [130].

doi:10.1371/journal.pntd.0002858.g002

[75]. Members of the family Bunyaviridae have been shown to bind platelets; specifically, hantaviruses bind to $\alpha_{\mathrm{v}} \beta_{3}$ or $\alpha_{\mathrm{IIb}} \beta_{3}$ integrins expressed on platelets and endothelial cells, contributing to viral dissemination, platelet activation, and induction of endothelial cell functions. These events reduce the number of circulating platelets and increase vascular permeability [74,76].

Platelets can also be activated by exposure to virus-infected cells. When HUVEC cells are infected with DENV, and then exposed to human platelets, the platelets become activated and bind to the endothelial cells [77]. Several viruses have shown in vitro affinity for the integrin receptors on both platelets and vascular endothelial cells: e.g., $\alpha_{\mathrm{V}} \beta_{3}$ binds coxsackievirus A9, human adenovirus type 2 , foot-and-mouth disease virus, echovirus 9 , and human paraechovirus 1 [78-82]; $\alpha_{\mathrm{V}} \beta_{3}$ and $\alpha_{\mathrm{IIb}} \beta 3$ bind hantavirus [76]; $\alpha_{2} \beta_{1}$ interacts with human echovirus 1 and rotavirus [83,84]. LASV and most isolates of the Old World arenaviruses use $\alpha$ dystroglycan $(\alpha-\mathrm{DG})[85,86]$. By using this receptor, those viruses can infect endothelial cells without cytotoxicity. However, as a result of interactions with virus particles or virus-infected cells, platelets will be activated to adhere to endothelial cells, thereby reducing the number of circulating platelets, altering endothelial cell function, and increasing vascular permeability.

There are other viral receptors that are present in cells of the immune system, such as Clec-2 and DC-SIGN that binds HIV $[68,87]$; DC-SIGN also shows affinity for other lentiviruses and
DENV [88,89]. DC-SIGN, Axl, and Tyro3 are Ebola virus and LASV receptors [90-93]. Ebola virus requires the cholesterol transporter Niemann-Pick C1 (NPC1) for cell entry [94]. This receptor is found in cells that are affected by HFV, such as gastrointestinal epithelial cells, and hepatocytes. Although all these receptors that bind $\mathrm{HFV}$ in target cells are also present in platelets and MKs (and, in some cases, have been shown to mediate virus internalization), it remains unknown whether they interact with platelets in vivo or if virus internalization leads to successful replication or even propagation of these viruses.

After binding viruses, platelets can engulf them and process them in small endocytic vesicles that are later fused with secretory granules that destroy the virus $[61,67,95]$. However, virus destruction is not always successful, and infected platelets can contribute to the dissemination of an infection [68] and to platelet dysfunction, as seen in HFRS [96].

\section{Immunological Destruction of Platelets or Their Precursor Cells}

There are at least three different ways in which the immune system can contribute to the reduction of platelet numbers (Figure 4). The first one is platelet sequestration by macrophages at the infection site and/or in the spleen. Viral activation of platelets induces an increased expression of $\mathrm{P}$-selectin that 


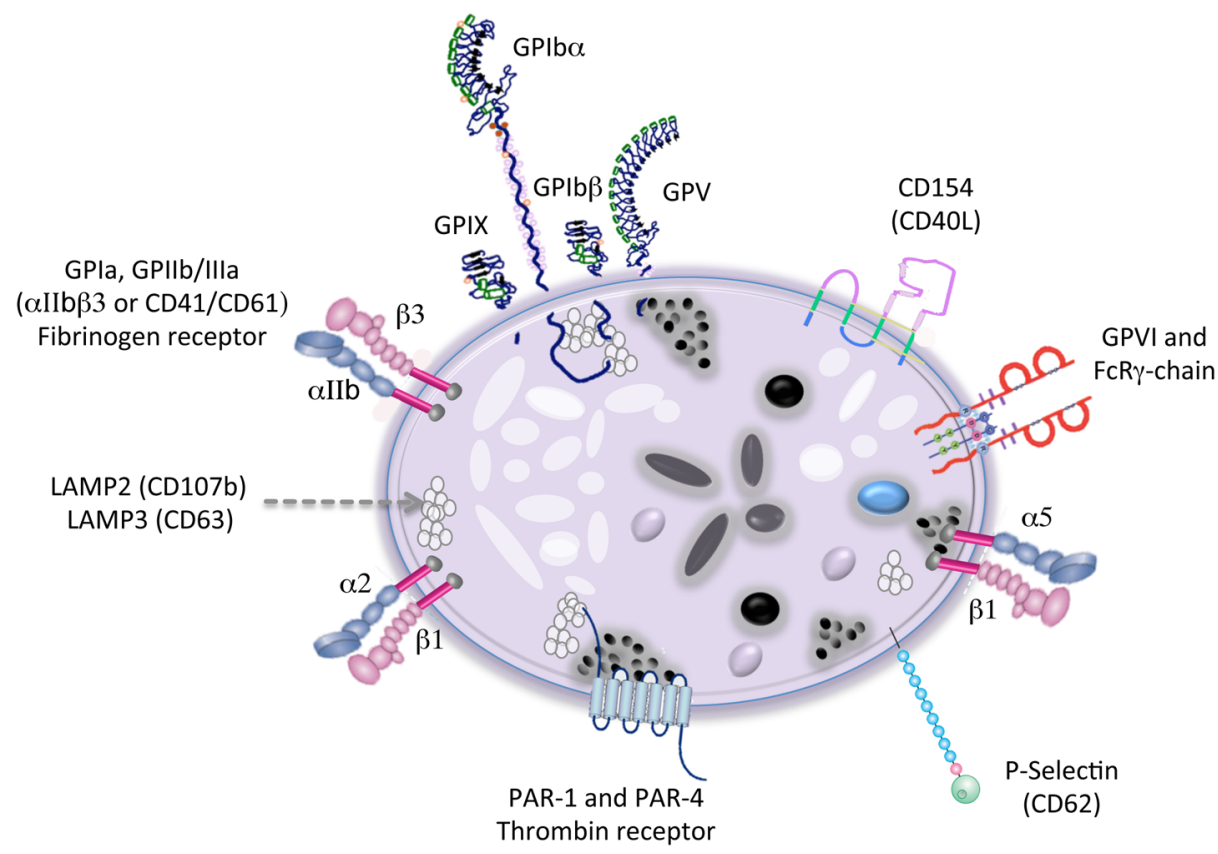

Figure 3. Platelet content. Membrane glycoproteins of platelets include GPla, GPIlb/llla (allbb3), or VLA-5 (fibrinogen receptor); GPIb/IX/V (vW and Mac-1 receptor); GPIc'-lla or VLA-6 (laminin receptor); and a2b1 GPVI (Collagen receptor). Alpha granules contain P-selectin; platelet factor 4; transforming factor-b1; chemokines; proteoglycan; platelet-derived growth factor; a2-plasmin inhibitor; vitronectin; laminin; CD63; TGFbeta; CLEC-2; thrombospondin; fibronectin; B-thromboglobulin; vWF; fibrinogen; coagulation factors V, XI, and XIII; integrins; thrombocidins; proteases; thrombin; prothrombin; kininogens; immunoglobulin family receptors; leucine-rich repeat family receptors; and other proinflammatory and immunemodulating factors. Dense granules hold ADP, ATP, calcium, serotonin, histamine, dopamine, phosphate, eicosanoids. Receptors for primary agonist include $P 2 X, P 2 Y_{1}$, and $P 2 Y_{12}$ (ADP); TPa-R and TPb-R (TXA $)_{2}$; PAR-1 and PAR-4 (thrombin); PAFR (platelet-activating factor); 5-HT $2 A$ (Serotonine); epinephrine receptors (catecholamines); Fc and complement $\mathrm{C}_{\mathrm{a}} / \mathrm{C} 5_{\mathrm{a}}$ receptors; and TLRs, CD40, CD40L, ICAM-2, DC-SIGN, JAM-A, and Fc $\gamma$ RIl. Between the platelet Metabolites are $\mathrm{TXA}_{2}$, sphingosine-1-phopate, PAF, glycogen, platelet factor 4 (PF-4), RANTES, connective tissue activating peptide 3 (CTAP-3), platelet basic protein, thymosin $\beta-4$ (T $\beta-4)$, fibrinopeptide B (FP-B), and fibrinopeptide A (FP-A).

doi:10.1371/journal.pntd.0002858.g003

functions as a receptor for macrophages [68]. As seen in SFTSV, another member of the Bunyaviridae associated with coagulation disorders, binding to platelets induces macrophage phagocytosis of platelets in the spleen, causing a decrease in circulating platelet numbers [97].

A second mechanism of platelet depletion is platelet-leukocyte aggregation and subsequent phagocytosis by macrophages. Activated platelets recruit leukocytes to inflamed endothelium, and neutrophils are the most frequent and rapidly recruited cells to the site of injury or inflammation $[98,99]$. Platelet-leukocyte interaction is mediated by the platelet GPIba protein and the leukocyte macrophage-1 antigen protein (MAC-1), also known as $\alpha_{\mathrm{M}} \beta_{2}$ integrin, complement receptor 3 (CR3) protein, $\mathrm{CD} 11 \mathrm{~B}$, and Integrin alpha-M (ITGAM). The mRNA for this integrin is 4-fold up-regulated in peripheral blood mononuclear cells (PBMC) exposed to LASV in comparison to PBMC exposed to a benign virus, ML29 [100]. ML29 is a nonpathogenic reassortant between Lassa and Mopeia viruses, with the $\mathrm{L}$ genome segment from Mopeia and the S segment from LASV. It is tempting to speculate that the up-regulation of this integrin on leukocytes promotes their aggregation with platelets and has a role in LASV pathogenesis, but many more studies are needed.

Platelets secrete chemokine proteins, such as CXCL1, CXCL4 (PF4), GXCL4L, GCL5, CXCL7, CXCL8 (IL-8), CXCL12, CXCR2, CGL2, CGL3, and CGL5, that promote angiogenesis and chemotaxis [101]. CXCL4 and CCL5 specifically induce monocyte migration and binding to the inflamed endothelium [102]. In a similar way, crosslinking of P-selectin glycoprotein ligand 1 (PSGL1) on monocytes by P-selectin expressed in platelets and endothelial cells enhances monocyte recruitment to the activated endothelium [101] as seen in adenovirus or DENV-endothelial infected cells $[77,103]$. This cascade of interactions not only regulates leukocyte trafficking to the inflamed site but also increases local platelet sequestration, phagocytosis and lysis.

A third mechanism of platelet depletion is their destruction mediated by platelet-virus associated antibodies. In a secondary DENV infection, antibodies against the prM viral protein facilitate efficient binding of immature particles to Fc-receptor-expressing cells [104]. Platelets express Fc $\gamma$ RIIa, which binds these anti-prMDENV complexes and renders them suceptible to destruction by the immune system. In addition, platelet-DENV complexes also bind the C3-complement molecule and platelet-associated IgM or IgG antibodies, targeting them for clearance by cells of the immune system [105,106]. Furthermore, DENV antibodies reacting against platelet glycoproteins can mediate destruction of platelets by complement or by the monocyte-macrophage system. Such antibodies could also suppress MK proliferation and maturation. Specifically, IgM anti-platelet autoantibodies not only induce platelet lysis via complement activation but also inhibit ADP-induced platelet aggregation [107]. 
Table 4. Four main mechanisms by which HFVs induce thrombocytopenia.

\begin{tabular}{|c|c|c|c|c|}
\hline Virus & $\begin{array}{l}{ }^{\mathrm{a}} \text { Destruction of } \\
\text { platelets by direct } \\
\text { interaction }\end{array}$ & $\begin{array}{l}\text { b/mmunological destruction of } \\
\text { platelet-viruses complexes }\end{array}$ & 'Megakaryocyte impairment & $\begin{array}{l}\text { dInhibition of platelet } \\
\text { function }\end{array}$ \\
\hline \multirow[t]{2}{*}{ Dengue } & Not yet described & Platelet-virus associated IgM or IgG & $\begin{array}{l}\text { Destruction of early blast and } \\
\text { hematopoietic DENV-infected } \\
\text { cells by macrophages and DC }\end{array}$ & $\begin{array}{l}\text { Platelet IgM auto-antibodies } \\
\text { inhibit ADP-induced platelet } \\
\text { aggregation }\end{array}$ \\
\hline & & $\begin{array}{l}\text { Platelet IgM auto-antibodies binding } \\
\text { the C3-complement molecule }\end{array}$ & & \\
\hline Hantavirus HFRS & $\alpha_{v} \beta_{3}$ and $\alpha_{\| l b} \beta_{3}$ & Not yet described & $\begin{array}{l}\text { Destruction of infected MK by } \\
\text { CTL [114] }\end{array}$ & $\begin{array}{l}\text { Defective platelet } \\
\text { aggregation [96] }\end{array}$ \\
\hline SFTS virus & Not yet described & $\begin{array}{l}\text { Increased platelet-virus } \\
\text { phagocytosis [97] }\end{array}$ & Not yet described & Not yet described \\
\hline Lassa virus & Not yet described & not yet described & Not yet described & $\begin{array}{l}\text { Unknown platelet } \\
\text { aggregation inhibitor } \\
{[127,137]}\end{array}$ \\
\hline Junín virus & Not yet described & Not yet described & $\begin{array}{l}\text { Increased bone marrow type } \\
\text { I IFN levels }\end{array}$ & $\begin{array}{l}\text { Unknown platelet } \\
\text { aggregation inhibitor [128] }\end{array}$ \\
\hline \multirow[t]{2}{*}{ Ebola } & Not yet described & Not yet described & Not yet described & $\begin{array}{l}\text { Elevated levels of type I IFN } \\
\text { [138] }\end{array}$ \\
\hline & & & & $\begin{array}{l}\text { Defective aggregation of } \\
\text { surviving platelets [139] }\end{array}$ \\
\hline \multicolumn{5}{|c|}{$\begin{array}{l}\text { aDestruction of platelets by direct interaction: HFV can bind platelets directly causing activation and granule release. } \\
\text { bImmunological destruction of platelet-virus complexes: Thrombocytopenia can be mediated by macrophages sequestration of platelet-virus complexes at the infection } \\
\text { site or/and in the spleen, platelets-virus-leukocyte aggregation and subsequent phagocytosis by macrophages or destruction mediated by platelet-virus associated } \\
\text { antibodies. } \\
{ }^{c} \text { Megakaryocytes or Megakaryocyte precursors impairment: HFV can infect megakaryocytes or their precursor causing reduction in platelets number or impairment in } \\
\text { their function. } \\
\text { dInhibition of platelet function: Some unidentified soluble factors present in plasma from infected patients can inhibit aggregation of platelets from healthy individuals. } \\
\text { doi:10.1371/journal.pntd.0002858.t004 }\end{array}$} \\
\hline
\end{tabular}

\section{Suppression of Megakaryocyte and Platelet Development}

Several viruses, like HIV-1, HCV, and human CMV, are able to replicate in MKs, and those infections are associated with thrombocytopenia and other thrombotic disorders [108-110]. Since platelets are derived from MKs, they express similar membrane receptors, therefore platelets may bind and internalize similar viruses. However, there are also differences in receptor expression and metabolic pathways among MK-precursors, mature MKs, and platelets that make them susceptible or resistant to specific viral infections. For instance, immature MKs express CD4 antigen on their surface, making them susceptible to HIV infection, while mature MKs and platelets do not express CD4 [68]. HHV-7 has the capacity to infect CD61+ megakaryoblast cells, increasing apoptosis of these cells and causing an impaired megakaryopoiesis [111]. Furthermore, HHV-6 is able to infect CD34+ hematopoietic progenitors cells, thereby suppressing thrombopoiesis [112]. DENV decreases platelet numbers by inhibiting progenitor cell development in the bone marrow. In vitro, early blast and hematopoietic cells in an intermediate state of differentiation were abortively infected, killed, and eliminated by DC phagocytosis [113]. Pathogenic hantaviruses can infect $\mathrm{MKs}$, in contrast to non-pathogenic hantaviruses. HTNVinfected MKs show no increased apoptosis or problems with differentiation, but they do show increased surface expression of HLA, making them good CTL targets and resulting in acute thrombocytopenia [114]. It has also been proposed that LCMVinduced thrombocytopenia in mouse is associated with the effect of IFN- $\alpha / \beta$ on MKs, leading to the generation of altered platelets [115].

Another mechanism that affects platelet formation is the decreased production of thrombopoietin (TPO) due to liver damage in $\mathrm{HCV}$ infection that results in suppression of development in the bone marrow [116].

\section{Inhibition of Platelet Function}

The integrin $\beta_{3}$ (ITGB3 or CD61+) subunit in platelets can combine with different partners, resulting in different integrin receptors with multiple functions. The integrin $\alpha_{\mathrm{v}} \beta_{3}$ is a receptor for cytotactin, fibronectin, laminin, matrix metalloproteinase-2, osteopontin, osteomodulin, prothrombin, thrombospondin, vitronectin, and von Willebrand factor. Integrin $\alpha_{\mathrm{IIb}} \beta_{3}$ is a receptor for fibronectin, fibrinogen, plasminogen, prothrombin, thrombospondin, and vitronectin. It mediates platelet-platelet interaction by binding of soluble fibrinogen. In acute DENV infection there is an increase in CD61+ on platelets and MKs containing viral proteins and RNA that suggests a link with platelet dysfunction and low platelet counts [105].

Arenaviruses have several mechanisms for inhibiting platelet function. In the LCMV-infected mouse model for thrombocytopenia, ITGB $3^{-/-}$mice developed a severe hemorrhagic anemia after infection, even with normal platelet counts, suggesting a key role of ITGB3 in protecting against bleeding [115]. In vitro exposure of human PBMC to a pathogenic arenavirus (LASV) increases the expression of ITGB3 mRNA by 12 -fold in contrast to ML29, the attenuated derivative of LASV mentioned earlier, that does not affect ITGB3 mRNA expression [100]. How LASV is affecting the function of ITGB3 in vivo remains to be explored, and the protection seen in the mouse model, combined with the increased expression in human PBMC exposed to a pathogenic virus, suggests that ITGB3 is playing an important role in arenavirus infections. 


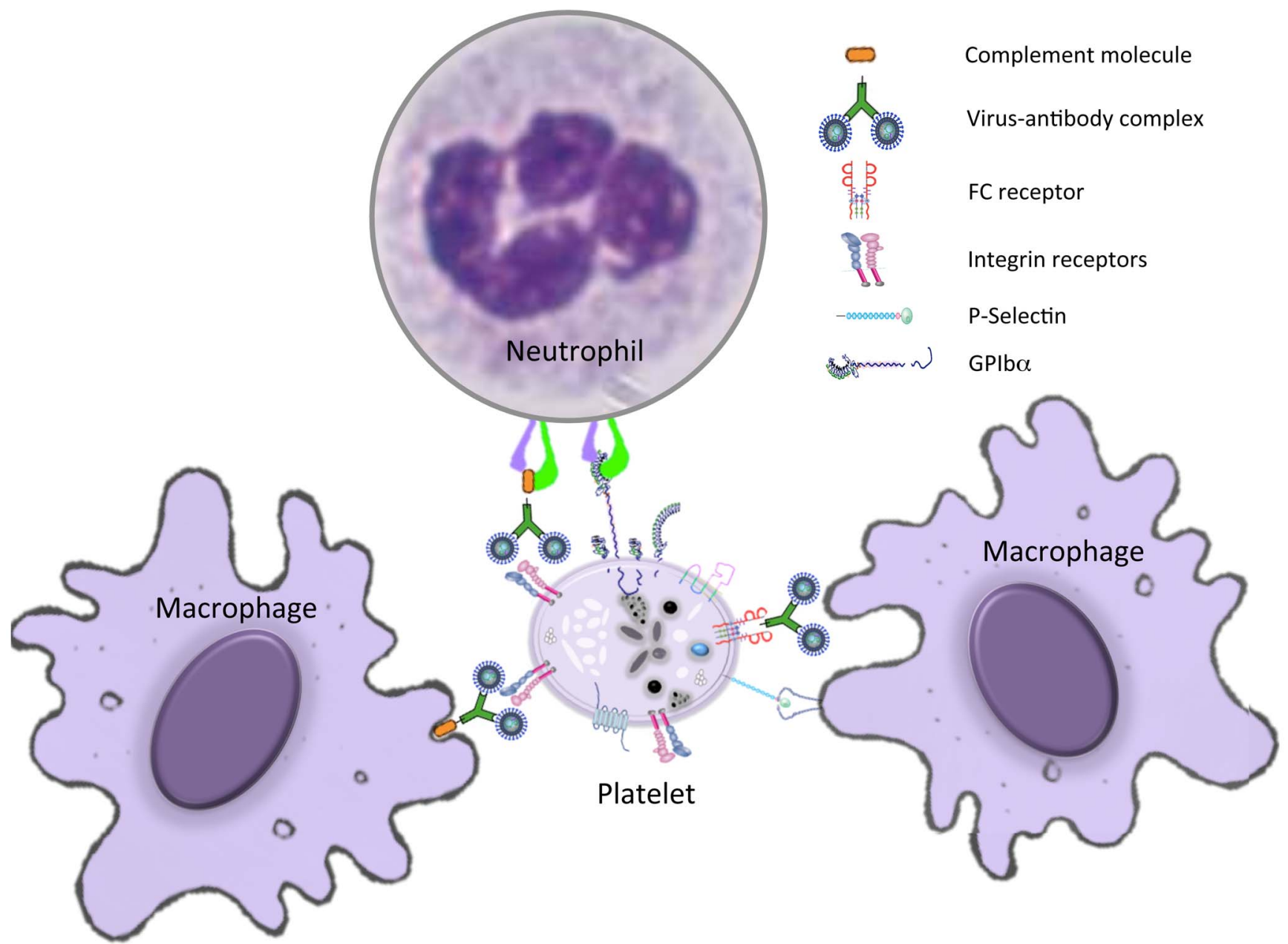

Figure 4. Immunological destruction of platelets. Platelets can interact with macrophages and neutrophils at the infection site and/or in the spleen through immuno-complexes or directly by cellular-ligand interactions. These interactions lead to either platelet sequestration or platelet destruction mediated by the immune system.

doi:10.1371/journal.pntd.0002858.g004

\section{Key Learning Points}

- Viral hemorrhagic fevers (VHF) are a group of zoonotic diseases characterized by fever and bleeding disorders that can progress to shock and death.

- Thrombocytopenia (reduction of platelet numbers) and depressed immune responses are hallmarks of VHF; platelets are involved in both processes, and their function is also compromised in these types of infections.

- Platelet-HFV interactions are poorly understood and seem to be different in each disease, but some mechanisms are common to all VHF pathogenesis.

- It is important to understand the role of platelets in each viral hemorrhagic fever disease to understand the pathogenesis mechanisms and identify new possible ways to prevent or treat this group of diseases.

\section{Five Key Papers in the Field}

1. Yeaman MR (1997) The role of platelets in antimicrobial host defense. Clin Infect Dis 25: 951-968; quiz 969-970.

2. George JN (2000) Platelets. Lancet 355: 1531-1539.

3. Youssefian T, Drouin A, Masse JM, Guichard J, Cramer EM (2002) Host defense role of platelets: engulfment of HIV and Staphylococcus aureus occurs in a specific subcellular compartment and is enhanced by platelet activation. Blood 99: 4021-4029.

4. Patel SR, Richardson JL, Schulze H, Kahle E, Galjart N, et al. (2005) Differential roles of microtubule assembly and sliding in proplatelet formation by megakaryocytes. Blood 106: 4076-4085.

5. Loria GD, Romagnoli PA, Moseley NB, Rucavado A, Altman JD (2013) Platelets support a protective immune response to LCMV by preventing splenic necrosis. Blood 121: 940-950. 
It is noteworthy that there are important differences between the LCMV mouse model for thrombocytopenia, in which IFN- $\alpha$ / $\beta$ mediates the decrease in platelet numbers, platelet dysfunction, and bleeding, and the LCMV primate model, in which the IFN- $\alpha$ / $\beta$ expression is not remarkable and yet there are bleeding signs [117-119]. Similarly, LCMV infection in humans more closely resembles a JUNV infection, with marked thrombocytopenia and platelet dysfunction [115], than a LASV infection, which is characterized by variable changes in platelet numbers and constant compromise of platelet function. IFN- $\alpha / \beta$ is affecting platelets either by a direct effect on MKs, leading to the production of altered platelets, or by the up-regulation of endothelial cell-derived platelet inhibitors, such as nitric oxide and prostacyclin, that indirectly contribute to the observed platelet dysfunction [115]. In vitro infections of MKs with JUNV showed impaired thrombopoiesis by decreasing pro-platelet formation, platelet release, and P-selectin externalization via a bystander effect. All these effects were associated with increased levels of type I IFN [120]. In addition, endothelial cells infected with a pathogenic JUNV strain showed an increase in nitric oxide (NO), endothelial nitric oxide synthase (eNOS), and PGI2 production [121]. Similarly, Pichinde virus (PICV, another arenavirus) induces endothelial cell permeability through the production of NO [122]. It is expected that the up-regulation of NO by JUNV will have similar effects on the permeability of endothelial cell layers.

It has been demonstrated that thrombomodulin (THBD) binds thrombin and blocks the ability of thrombin to activate platelets. THBD also completely blocked tissue factor-induced microparticle

\section{References}

1. Geisbert TW, Jahrling PB (2004) Exotic emerging viral diseases: progress and challenges. Nat Med 10: S110-S121.

2. Bray M (2005) Pathogenesis of viral hemorrhagic fever. Curr Opin Immunol 17: 399-403.

3. Lukashevich IS, Maryankova R, Vladyko AS, Nashkevich N, Koleda S, et al. (1999) Lassa and Mopeia virus replication in human monocytes/macrophages and in endothelial cells: different effects on IL-8 and TNF-alpha gene expression. J Med Virol 59: 552-560.

4. Mahanty S, Hutchinson K, Agarwal S, McRae M, Rollin PE, et al. (2003) Cutting edge: impairment of dendritic cells and adaptive immunity by Ebola and Lassa viruses. J Immunol 170: 2797-2801.

5. Macal M, Lewis GM, Kunz S, Flavell R, Harker JA, et al. (2012) Plasmacytoid dendritic cells are productively infected and activated through TLR-7 early after arenavirus infection. Cell Host Microbe 11: 617-630.

6. Fang S, Wu Y, Wu N, Zhang J, An J (2013) Recent advances in DENV receptors. ScientificWorldJournal 2013: 684690

7. Gommet C, Billecocq A, Jouvion G, Hasan M, Zaverucha do Valle T, et al. (2011) Tissue tropism and target cells of NSs-deleted rift valley fever virus in live immunodeficient mice. PLoS Negl Trop Dis 5: e1421.

8. Peyrefitte CN, Perret M, Garcia S, Rodrigues R, Bagnaud A, et al. (2010) Differential activation profiles of Crimean-Congo hemorrhagic fever virus- and Dugbe virus-infected antigen-presenting cells. J Gen Virol 91: 189-198.

9. La Ruche G, Souares Y, Armengaud A, Peloux-Petiot F, Delaunay P, et al. (2010) First two autochthonous dengue virus infections in metropolitan France, September 2010. Euro Surveill 15: 19676.

10. Kurolt IC, Betica-Radic L, Dakovic-Rode O, Franco L, Zelena H, et al. (2013) Molecular characterization of dengue virus 1 from autochthonous dengue fever cases in Croatia. Glin Microbiol Infect 19: E163-165.

11. WHO (2012) Outbreak news. Dengue fever in Madeira,Portugal. Wkly Epidemiol Rec 87: 413.

12. Radke EG, Gregory CJ, Kintziger KW, Sauber-Schatz EK, Hunsperger EA, et al. (2012) Dengue outbreak in Key West, Florida, USA, 2009. Emerg Infect Dis 18: $135-137$

13. Kouri GP, Guzman MG, Bravo JR, Triana C (1989) Dengue haemorrhagic fever/dengue shock syndrome: lessons from the Cuban epidemic, 1981. Bull World Health Organ 67: 375-380.

14. Barrett AD, Higgs S (2007) Yellow fever: a disease that has yet to be conquered. Annu Rev Entomol 52: 209-229.

15. WHO (2011) Yellow fever. Fact sheet No. 100. Available: http://www.who. int/mediacentre/factsheets/fs100/en/. Accessed 13 May 2014.

16. Mehla R, Kumar SR, Yadav P, Barde PV, Yergolkar PN, et al. (2009) Recent ancestry of Kyasanur Forest disease virus. Emerg Infect Dis 15: 1431-1437. formation [123-124]. Additionally, platelets contain functional THBD [125], and the platelet alpha-granule protein PF4 enhances activated protein $\mathrm{C}$ (APG) generation by soluble and membrane THBD in endothelial cells [126]. PBMC exposed to a pathogenic arenavirus (LASV) increased expression of THBD mRNA by 14fold. In contrast, the attenuated ML29 inhibits THBD mRNA expression. This pattern was observed also at the protein level in PBMC and DC for both soluble and membrane-bound THBD [100]. Serum from LASV-infected patients suffering hemorrhagic symptoms contains an unidentified soluble factor able to inhibit aggregation of platelets from healthy individuals [127]. Similarly, there is evidence of an inhibitor in plasma of JUNV-infected patients [128] that is not neutralized by plasma containing high titers of protective antibodies against JUNV [129], suggesting that this is not a virus-derived molecule. This factor could be THBD that, after an overexpression induced by LASV, inhibits platelet activation through thrombin binding and, at the same time, prevents thrombin production by APC. As a consequence, there is an increased susceptibility to hemorrhagic episodes during LF disease [100].

In conclusion, HFVs all induce homeostatic abnormalities, inhibit the antiviral immune response, and display high levels of viremia. Platelets are peripheral blood elements that play roles in both homeostasis and inflammation. Platelet-HFV interactions are poorly understood and seem to be different in each disease, but there are similar mechanisms underlying all VHF pathogenesis. The identification of such mechanisms can lead to the development of new treatment options for this group of diseases that kill millions of human beings each year.

17. Madani TA (2005) Alkhumra virus infection, a new viral hemorrhagic fever in Saudi Arabia. J Infect 51: 91-97.

18. Dodd KA, Bird BH, Khristova ML, Albarino CG, Carroll SA, et al. (2011) Ancient ancestry of KFDV and AHFV revealed by complete genome analyses of viruses isolated from ticks and mammalian hosts. PLoS Negl Trop Dis 5: e1352.

19. Richmond JK, Baglole DJ (2003) Lassa fever: epidemiology, clinical features, and social consequences. BMJ 327: 1271-1275.

20. Asogun DA, Adomeh DI, Ehimuan J, Odia I, Hass M, et al. (2012) Molecular diagnostics for lassa fever at Irrua specialist teaching hospital, Nigeria: lessons learnt from two years of laboratory operation. PLoS Negl Trop Dis 6: e1839.

21. Briese T, Paweska JT, McMullan LK, Hutchison SK, Street C, et al. (2009) Genetic detection and characterization of Lujo virus, a new hemorrhagic fever-associated arenavirus from southern Africa. PLoS Pathog 5: e1000455.

22. Maiztegui JI (1975) Clinical and epidemiological patterns of Argentine haemorrhagic fever. Bull World Health Organ 52: 567-575.

23. Maiztegui JI, McKee KT, Jr., Barrera Oro JG, Harrison LH, Gibbs PH, et al. (1998) Protective efficacy of a live attenuated vaccine against Argentine hemorrhagic fever. AHF Study Group. J Infect Dis 177: 277-283.

24. ProMED (2012) Bolivian Hemorrhagic Fever. Available: http://www. promedmail.org/direct.php?id $=20120730.1220842$. Accessed 13 May 2014 .

25. Fulhorst CF, Cajimat MN, Milazzo ML, Paredes H, de Manzione NM, et al. (2008) Genetic diversity between and within the arenavirus species indigenous to western Venezuela. Virology 378: 205-213.

26. The Travel Doctor (2012) Outbreak of Venezuelan hemorrhagic fever (VHF). Available: http://www.thetraveldoctor.com/alert_view.php?alertsid = 207\&country = Venezuela. Accessed 13 May 2014.

27. Bi Z, Formenty PB, Roth CE (2008) Hantavirus infection: a review and global update. J Infect Dev Ctries 2: 3-23.

28. Klempa B, Tkachenko EA, Dzagurova TK, Yunicheva YV, Morozov VG, et al. (2008) Hemorrhagic fever with renal syndrome caused by 2 lineages of Dobrava hantavirus, Russia. Emerg Infect Dis 14: 617-625.

29. Krautkramer E, Zeier M, Plyusnin A (2013) Hantavirus infection: an emerging infectious disease causing acute renal failure. Kidney Int 83: 23-27.

30. Ergonul O (2006) Crimean-Congo haemorrhagic fever. Lancet Infect Dis 6: 203-214.

31. PRESSTV (2009) Congo-Crimean fever proves deadly in Iran. Available: http://edition.presstv.ir/detail/105532.html. Accessed 13 May 2014.

32. Shoemaker T, Boulianne C, Vincent MJ, Pezzanite L, Al-Qahtani MM, et al. (2002) Genetic analysis of viruses associated with emergence of Rift Valley fever in Saudi Arabia and Yemen, 2000-01. Emerg Infect Dis 8: 1415-1420. 
33. Nicolas G, Durand B, Duboz R, Rakotondravao R, Chevalier V (2013) Description and analysis of the cattle trade network in the Madagascar highlands: potential role in the diffusion of Rift Valley fever virus. Acta Trop 126: 19-27.

34. Yu XJ, Liang MF, Zhang SY, Liu Y, Li JD, et al. (2011) Fever with thrombocytopenia associated with a novel bunyavirus in China. N Engl J Med 364: 1523-1532.

35. ProMED (2013) Severe Fever with Thrombocytopenia Syndrome - Japan. 2005 Fatality. Available: http://www.promedmail.org/direct.php?id = 20130227 . 1562954. Accessed 13 May 2014.

36. Kim KH, Yi J, Kim G, Choi SJ, Jun KI, et al. (2013) Severe fever with thrombocytopenia syndrome, South Korea, 2012. Emerg Infect Dis 19: 1892 1894.

37. Bao CJ, Guo XL, Qi X, Hu JL, Zhou MH, et al. (2011) A family cluster of infections by a newly recognized bunyavirus in eastern China, 2007: further evidence of person-to-person transmission. Clin Infect Dis 53: 1208-1214.

38. Leroy EM, Gonzalez JP, Baize S (2011) Ebola and Marburg haemorrhagic fever viruses: major scientific advances, but a relatively minor public health threat for Africa. Clin Microbiol Infect 17: 964-976.

39. WHO (2012) Marburg haemorrhagic fever in Uganda - update. Accessed: http://www.who.int/csr/don/2012_10_31/en/. Accessed 13 May 2014.

40. Towner JS, Pourrut X, Albarino CG, Nkogue CN, Bird BH, et al. (2007) Marburg virus infection detected in a common African bat. PLoS ONE 2: e764.

41. Khan SH, Goba A, Chu M, Roth C, Healing T, et al. (2008) New opportunities for field research on the pathogenesis and treatment of Lassa fever. Antiviral Res 78: 103-115.

42. Gould EA, Solomon T (2008) Pathogenic flaviviruses. Lancet 371: 500-509.

43. Gardner CL, Ryman KD (2010) Yellow fever: a reemerging threat. Clin Lab Med 30: 237-260.

44. Kortepeter MG, Bausch DG, Bray M (2011) Basic clinical and laboratory features of filoviral hemorrhagic fever. J Infect Dis 204 Suppl 3: S810-816.

45. Ranjit S, Kissoon N (2011) Dengue hemorrhagic fever and shock syndromes. Pediatr Crit Care Med 12: 90-100.

46. Deng B, Zhang S, Geng Y, Zhang Y, Wang Y, et al. (2012) Cytokine and chemokine levels in patients with severe fever with thrombocytopenia syndrome virus. PLoS ONE 7: e41365.

47. Feldmann H, Bugany H, Mahner F, Klenk HD, Drenckhahn D, et al. (1996) Filovirus-induced endothelial leakage triggered by infected monocytes/ macrophages. J Virol 70: 2208-2214.

48. Gupta M, Mahanty S, Ahmed R, Rollin PE (2001) Monocyte-derived human macrophages and peripheral blood mononuclear cells infected with ebola virus secrete MIP-1alpha and TNF-alpha and inhibit poly-IC-induced IFN-alpha in vitro. Virology 284: 20-25.

49. Fennewald SM, Aronson JF, Zhang L, Herzog NK (2002) Alterations in NFkappaB and RBP-Jkappa by arenavirus infection of macrophages in vitro and in vivo. J Virol 76: 1154-1162.

50. McElroy AK, Nichol ST (2012) Rift Valley fever virus inhibits a proinflammatory response in experimentally infected human monocyte derived macrophages and a pro-inflammatory cytokine response may be associated with patient survival during natural infection. Virology 422: 6-12.

51. Stroher U, West E, Bugany H, Klenk HD, Schnittler HJ, et al. (2001) Infection and activation of monocytes by Marburg and Ebola viruses. J Virol 75: 1102511033.

52. Baize S, Leroy EM, Georges AJ, Georges-Courbot MC, Capron M, et al. (2002) Inflammatory responses in Ebola virus-infected patients. Clin Exp Immunol 128: 163-168.

53. Patel SR, Richardson JL, Schulze H, Kahle E, Galjart N, et al. (2005) Differential roles of microtubule assembly and sliding in proplatelet formation by megakaryocytes. Blood 106: 4076-4085.

54. George JN (2000) Platelets. Lancet 355: 1531-1539.

55. Kerrigan SW, Cox D (2010) Platelet-bacterial interactions. Cell Mol Life Sci 67: 513-523.

56. Yeaman MR (1997) The role of platelets in antimicrobial host defense. Clin Infect Dis 25: 951-968; quiz 969-970.

57. Beaulieu LM, Freedman JE (2010) The role of inflammation in regulating platelet production and function: Toll-like receptors in platelets and megakaryocytes. Thromb Res 125: 205-209.

58. Tang YQ, Yeaman MR, Selsted ME (2002) Antimicrobial peptides from human platelets. Infect Immun 70: 6524-6533.

59. Kalvegren H, Majeed M, Bengtsson T (2003) Chlamydia pneumoniae binds to platelets and triggers P-selectin expression and aggregation: a causal role in cardiovascular disease? Arterioscler Thromb Vasc Biol 23: 1677-1683.

60. Bertling A, Niemann S, Uekotter A, Fegeler W, Lass-Florl C, et al. (2010) Candida albicans and its metabolite gliotoxin inhibit platelet function via interaction with thiols. Thromb Haemost 104: 270-278.

61. Danon D, Jerushalmy Z, De Vries A (1959) Incorporation of influenza virus in human blood platelets in vitro. Electron microscopical observation. Virology 9: $719-722$

62. Jerushalmy Z, Kohn A, De Vries A (1961) Interaction of myxoviruses with human blood platelets in vitro. Proc Soc Exp Biol Med 106: 462-466.

63. De Harven E, Friend C (1960) Further electron microscope studies of a mouse leukemia induced by cell-free filtrates. J Biophys Biochem Cytol 7: 747-752.
64. Brown WM, Axelrad AA (1976) Effect of Friend leukemia virus on megakaryocytes and platelets in mice. Int J Cancer 18: 764-773.

65. Bik T, Sarov I, Livne A (1982) Interaction between vaccinia virus and human blood platelets. Blood 59: 482-487.

66. Zucker-Franklin D, Cao YZ (1989) Megakaryocytes of human immunodeficiency virus-infected individuals express viral RNA. Proc Natl Acad Sci U S A 86: 5595-5599.

67. Zucker-Franklin D, Seremetis S, Zheng ZY (1990) Internalization of human immunodeficiency virus type I and other retroviruses by megakaryocytes and platelets. Blood 75: 1920-1923.

68. Flaujac C, Boukour S, Cramer-Borde E (2010) Platelets and viruses: an ambivalent relationship. Cell Mol Life Sci 67: 545-556.

69. McKay DG, Margaretten W (1967) Disseminated intravascular coagulation in virus diseases. Arch Intern Med 120: 129-152.

70. Niewold TB, Bundrick JB (2006) Disseminated intravascular coagulation due to cytomegalovirus infection in an immunocompetent adult treated with plasma exchange. Am J Hematol 81: 454-457.

71. Limbos MA, Lieberman JM (1996) Disseminated intravascular coagulation associated with rotavirus gastroenteritis: report of two cases. Clin Infect Dis 22: $834-836$

72. Shimony N, Elkin G, Kolodkin-Gal D, Krasny L, Urieli-Shoval S, et al. (2009) Analysis of adenoviral attachment to human platelets. Virol J 6: 25

73. Aslam R, Speck ER, Kim M, Crow AR, Bang KW, et al. (2006) Platelet Tolllike receptor expression modulates lipopolysaccharide-induced thrombocytopenia and tumor necrosis factor-alpha production in vivo. Blood 107: 637-641.

74. Gavrilovskaya IN, Gorbunova EE, Mackow ER (2010) Pathogenic hantaviruses direct the adherence of quiescent platelets to infected endothelial cells. J Virol 84: 4832-4839.

75. Blair P, Rex S, Vitseva O, Beaulieu L, Tanriverdi K, et al. (2009) Stimulation of Toll-like receptor 2 in human platelets induces a thromboinflammatory response through activation of phosphoinositide 3-kinase. Circ Res 104: 346354 .

76. Gavrilovskaya IN, Brown EJ, Ginsberg MH, Mackow ER (1999) Cellular entry of hantaviruses which cause hemorrhagic fever with renal syndrome is mediated by beta3 integrins. J Virol 73: 3951-3959.

77. Krishnamurti C, Peat RA, Cutting MA, Rothwell SW (2002) Platelet adhesion to dengue-2 virus-infected endothelial cells. Am J Trop Med Hyg 66: 435-441.

78. Roivainen M, Hyypia T, Piirainen L, Kalkkinen N, Stanway G, et al. (1991) RGD-dependent entry of coxsackievirus A9 into host cells and its bypass after cleavage of VP1 protein by intestinal proteases. J Virol 65: 4735-4740.

79. Wickham TJ, Mathias P, Cheresh DA, Nemerow GR (1993) Integrins alpha v beta 3 and alpha $\mathrm{v}$ beta 5 promote adenovirus internalization but not virus attachment. Cell 73: 309-319.

80. Berinstein A, Roivainen M, Hovi T, Mason PW, Baxt B (1995) Antibodies to the vitronectin receptor (integrin alpha $\mathrm{V}$ beta 3 ) inhibit binding and infection of foot-and-mouth disease virus to cultured cells. J Virol 69: 2664-2666.

81. Nelsen-Salz B, Eggers HJ, Zimmermann H (1999) Integrin alpha(v)beta3 (vitronectin receptor) is a candidate receptor for the virulent echovirus 9 strain Barty. J Gen Virol 80 (Pt 9): 2311-2313.

82. Triantafilou K, Triantafilou M, Takada Y, Fernandez N (2000) Human parechovirus 1 utilizes integrins alphavbeta 3 and alphavbetal as receptors. J Virol 74: 5856-5862.

83. Fleming FE, Graham KL, Takada Y, Coulson BS (2011) Determinants of the specificity of rotavirus interactions with the alpha2betal integrin. J Biol Chem 286: 6165-6174.

84. Bergelson JM, St John NF, Kawaguchi S, Pasqualini R, Berdichevsky F, et al. (1994) The I domain is essential for echovirus 1 interaction with VLA-2. Cell Adhes Commun 2: 455-464.

85. Cao W, Henry MD, Borrow P, Yamada H, Elder JH, et al. (1998) Identification of alpha-dystroglycan as a receptor for lymphocytic choriomeningitis virus and Lassa fever virus. Science 282: 2079-2081.

86. Kunz S, Rojek JM, Perez M, Spiropoulou CF, Oldstone MB (2005) Characterization of the interaction of lassa fever virus with its cellular receptor alpha-dystroglycan. J Virol 79: 5979-5987.

87. Chaipan C, Soilleux EJ, Simpson P, Hofmann H, Gramberg T, et al. (2006) DC-SIGN and CLEC-2 mediate human immunodeficiency virus type 1 capture by platelets. J Virol 80: 8951-8960.

88. Tassaneetrithep B, Burgess TH, Granelli-Piperno A, Trumpfheller C, Finke J, et al. (2003) DC-SIGN (CD209) mediates dengue virus infection of human dendritic cells. J Exp Med 197: 823-829.

89. Curtis BM, Scharnowske S, Watson AJ (1992) Sequence and expression of a membrane-associated C-type lectin that exhibits CD4-independent binding of human immunodeficiency virus envelope glycoprotein gp120. Proc Natl Acad Sci U S A 89: 8356-8360.

90. Alvarez CP, Lasala F, Carrillo J, Muniz O, Corbi AL, et al. (2002) C-type lectins DC-SIGN and L-SIGN mediate cellular entry by Ebola virus in cis and in trans. J Virol 76: 6841-6844.

91. Shimojima M, Ikeda Y, Kawaoka Y (2007) The mechanism of Axl-mediated Ebola virus infection. J Infect Dis 196 Suppl 2: S259-263.

92. Hunt CL, Kolokoltsov AA, Davey RA, Maury W (2011) The Tyro3 receptor kinase Axl enhances macropinocytosis of Zaire ebolavirus. J Virol 85: 334-347.

93. Shimojima M, Stroher U, Ebihara H, Feldmann H, Kawaoka Y (2012) Identification of cell surface molecules involved in dystroglycan-independent Lassa virus cell entry. J Virol 86: 2067-2078. 
94. Carette JE, Raaben M, Wong AC, Herbert AS, Obernosterer G, et al. (2011) Ebola virus entry requires the cholesterol transporter Niemann-Pick C1. Nature 477: 340-343.

95. Youssefian T, Drouin A, Masse JM, Guichard J, Cramer EM (2002) Host defense role of platelets: engulfment of HIV and Staphylococcus aureus occurs in a specific subcellular compartment and is enhanced by platelet activation. Blood 99: 4021-4029.

96. Cosgriff TM, Lee HW, See AF, Parrish DB, Moon JS, et al. (1991) Platelet dysfunction contributes to the haemostatic defect in haemorrhagic fever with renal syndrome. Trans R Soc Trop Med Hyg 85: 660-663.

97. Jin C, Liang M, Ning J, Gu W, Jiang H, et al. (2012) Pathogenesis of emerging severe fever with thrombocytopenia syndrome virus in C57/BL6 mouse model. Proc Natl Acad Sci U S A 109: 10053-10058.

98. Diacovo TG, Roth SJ, Buccola JM, Bainton DF, Springer TA (1996) Neutrophil rolling, arrest, and transmigration across activated, surfaceadherent platelets via sequential action of P-selectin and the beta 2-integrin CD11b/CD18. Blood 88: 146-157.

99. Ghasemzadeh M, Hosseini E (2013) Platelet-leukocyte crosstalk: Linking proinflammatory responses to procoagulant state. Thromb Res 131: 191-197.

100. Zapata JC, Carrion R Jr, Patterson JL, Crasta O, Zhang Y, et al. (2013) Transcriptome Analysis of Human Peripheral Blood Mononuclear Cells Exposed to Lassa Virus and to the Attenuated Mopeia/Lassa Reassortant 29 (ML29), a Vaccine Candidate. PLoS Negl Trop Dis 7: e2406.

101. von Hundelshausen P, Petersen F, Brandt E (2007) Platelet-derived chemokines in vascular biology. Thromb Haemost 97: 704-713.

102. von Hundelshausen P, Weber KS, Huo Y, Proudfoot AE, Nelson PJ, et al. (2001) RANTES deposition by platelets triggers monocyte arrest on inflamed and atherosclerotic endothelium. Circulation 103: 1772-1777.

103. Othman M, Labelle A, Mazzetti I, Elbatarny HS, Lillicrap D (2007) Adenovirus-induced thrombocytopenia: the role of von Willebrand factor and P-selectin in mediating accelerated platelet clearance. Blood 109: 2832 2839.

104. Rodenhuis-Zybert IA, van der Schaar HM, da Silva Voorham JM, van der Ende-Metselaar H, Lei HY, et al. (2010) Immature dengue virus: a veiled pathogen? PLoS Pathog 6: e1000718.

105. Noisakran S, Onlamoon N, Pattanapanyasat K, Hsiao HM, Songprakhon P, et al. (2012) Role of CD61+ cells in thrombocytopenia of dengue patients. Int J Hematol 96: 600-610.

106. Saito M, Oishi K, Inoue S, Dimaano EM, Alera MT, et al. (2004) Association of increased platelet-associated immunoglobulins with thrombocytopenia and the severity of disease in secondary dengue virus infections. Clin Exp Immunol 138: 299-303.

107. Lin CF, Lei HY, Liu CC, Liu HS, Yeh TM, et al. (2001) Generation of IgM anti-platelet autoantibody in dengue patients. J Med Virol 63: 143-149.

108. Chelucci G, Federico M, Guerriero R, Mattia G, Casella I, et al. (1998) Productive human immunodeficiency virus- 1 infection of purified megakaryocytic progenitors/precursors and maturing megakaryocytes. Blood 91: 12251234 .

109. Li X, Jeffers LJ, Garon C, Fischer ER, Scheffel J, et al. (1999) Persistence of hepatitis $\mathrm{C}$ virus in a human megakaryoblastic leukaemia cell line. J Viral Hepat 6: 107-114.

110. Crapnell K, Zanjani ED, Chaudhuri A, Ascensao JL, St Jeor S, et al. (2000) In vitro infection of megakaryocytes and their precursors by human cytomegalovirus. Blood 95: 487-493.

111. Gonelli A, Mirandola P, Grill V, Secchiero P, Zauli G (2002) Human herpesvirus 7 infection impairs the survival/differentiation of megakaryocytic cells. Haematologica 87: 1223-1225.

112. Isomura H, Yoshida M, Namba H, Fujiwara N, Ohuchi R, et al. (2000) Suppressive effects of human herpesvirus- 6 on thrombopoietin-inducible megakaryocytic colony formation in vitro. J Gen Virol 81: 663-673.

113. La Russa VF, Innis BL (1995) Mechanisms of dengue virus-induced bone marrow suppression. Baillieres Clin Haematol 8: 249-270.

114. Lutteke N, Raftery MJ, Lalwani P, Lee MH, Giese T, et al. (2010) Switch to high-level virus replication and HLA class I upregulation in differentiating megakaryocytic cells after infection with pathogenic hantavirus. Virology 405: $70-80$.

115. Iannacone M, Sitia G, Isogawa M, Whitmire JK, Marchese P, et al. (2008) Platelets prevent IFN-alpha/beta-induced lethal hemorrhage promoting CTL- dependent clearance of lymphocytic choriomeningitis virus. Proc Natl Acad Sci U S A 105: 629-634.

116. Weksler BB (2007) Review article: the pathophysiology of thrombocytopenia in hepatitis $\mathrm{C}$ virus infection and chronic liver disease. Aliment Pharmacol Ther 26 Suppl 1: 13-19.

117. Binder D, Fehr J, Hengartner H, Zinkernagel RM (1997) Virus-induced transient bone marrow aplasia: major role of interferon-alpha/beta during acute infection with the noncytopathic lymphocytic choriomeningitis virus. J Exp Med 185: 517-530.

118. Loria GD, Romagnoli PA, Moseley NB, Rucavado A, Altman JD (2013) Platelets support a protective immune response to LCMV by preventing splenic necrosis. Blood 121: 940-950.

119. Zapata JC, Pauza CD, Djavani MM, Rodas JD, Moshkoff D, et al. (2011) Lymphocytic choriomeningitis virus (LCMV) infection of macaques: a model for Lassa fever. Antiviral Res 92: 125-138.

120. Pozner RG, Ure AE, Jaquenod de Giusti C, D'Atri LP, Italiano JE, et al. (2010) Junin virus infection of human hematopoietic progenitors impairs in vitro proplatelet formation and platelet release via a bystander effect involving type I IFN signaling. PLoS Pathog 6: e1000847.

121. Gomez RM, Pozner RG, Lazzari MA, D’Atri LP, Negrotto S, et al. (2003) Endothelial cell function alteration after Junin virus infection. Thromb Haemost 90: 326-333.

122. Brocato RL, Voss TG (2009) Pichinde virus induces microvascular endothelial cell permeability through the production of nitric oxide. Virol J 6: 162.

123. Esmon NL, Carroll RC, Esmon CT (1983) Thrombomodulin blocks the ability of thrombin to activate platelets. J Biol Chem 258: 12238-12242.

124. Cafer Adiguzel, Omer Iqbal, Daniel Fareed, Debra Hoppensteadt, Walter Jeske MS, et al. (2008) Modulation of Platelet Function by Recombinant Thrombomodulin Hematologic Implications. The FASEB Journal 22 (Meeting Abstract Supplement): 1118.1111.

125. Suzuki K, Nishioka J, Hayashi T, Kosaka Y (1988) Functionally active thrombomodulin is present in human platelets. J Biochem 104: 628-632.

126. Slungaard A (2004) Platelet factor 4 modulation of the thrombomodulinprotein C system. Crit Care Med 32: S331-335.

127. Cummins D, Fisher-Hoch SP, Walshe KJ, Mackie IJ, McCormick JB, et al (1989) A plasma inhibitor of platelet aggregation in patients with Lassa fever. Br J Haematol 72: 543-548.

128. Cummins D, Molinas FC, Lerer G, Maiztegui JI, Faint R, et al. (1990) A plasma inhibitor of platelet aggregation in patients with Argentine hemorrhagic fever. Am J Trop Med Hyg 42: 470-475.

129. Marta RF, Heller MV, Maiztegui JI, Molinas FC (1993) Further studies on the plasma inhibitor of platelet activation in Argentine hemorrhagic fever. Thromb Haemost 69: 526-527.

130. Blair P, Flaumenhaft R (2009) Platelet alpha-granules: basic biology and clinical correlates. Blood Rev 23: 177-189.

131. WHO (2013) Dengue control. Available: http://www.who.int/denguecontrol/ en/. Accessed 13 May 2014

132. Mourya DT, Yadav PD, Sandhya VK, Reddy S (2013) Spread of Kyasanur Forest disease, Bandipur Tiger Reserve, India, 2012-2013. Emerg Infect Dis 19: $1540-1541$.

133. WHO (2010) Crimean-Congo haemorrhagic fever (CCHF) and Dengue in Pakistan. Available: http://www.who.int/csr/don/2010_10_25a/en/. Accessed 13 May 2014

134. WHO (2012) Rift Valley fever in Mauritania. Available: http://www.who.int/ csr/don/2012_11_01/en/. Accessed 13 May 2014.

135. CDC (2012) Outbreak postings. Available: http://www.cdc.gov/ncezid/ dhcpp/vspb/outbreaks.html. Accessed 13 May 2014.

136. Chen JP, Cosgriff TM (2000) Hemorrhagic fever virus-induced changes in hemostasis and vascular biology. Blood Coagul Fibrinolysis 11: 461-483.

137. Fisher-Hoch S, McCormick JB, Sasso D, Craven RB (1988) Hematologic dysfunction in Lassa fever. J Med Virol 26: 127-135.

138. Villinger F, Rollin PE, Brar SS, Chikkala NF, Winter J, et al. (1999) Markedly elevated levels of interferon (IFN)-gamma, IFN-alpha, interleukin (IL)-2, IL-10, and tumor necrosis factor-alpha associated with fatal Ebola virus infection. J Infect Dis 179 Suppl 1: S188-191.

139. Feldmann H, Klenk HD (1996) Filoviruses. In: Baron S, editor. Medical Microbiology. 4th edition. Galveston (TX): University of Texas Medical Branch at Galveston. 